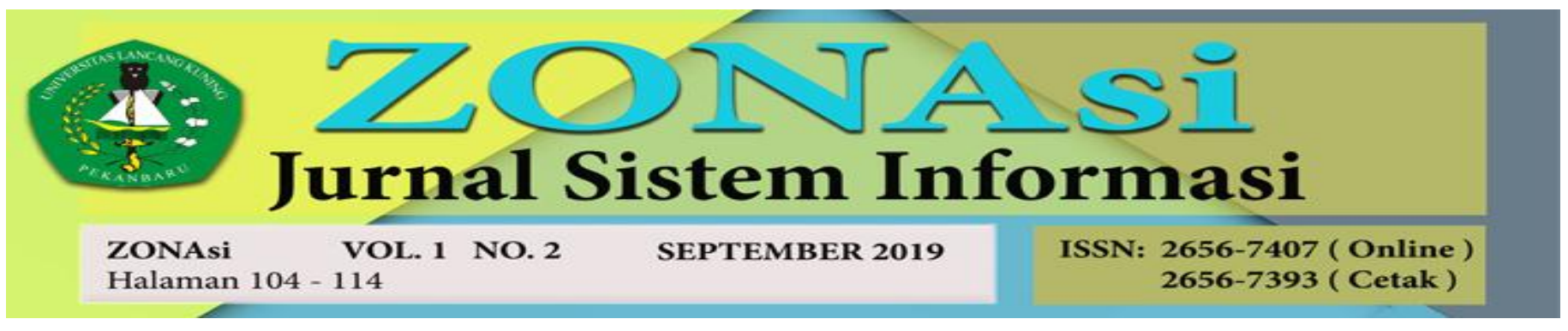

\title{
Sistem Informasi Catering di Ratu Catering Berbasis Web
}

\author{
Nurholidan Siregar ${ }^{1}$, Zamzami², Guntoro ${ }^{3}$ \\ ${ }^{1,2,3}$ Program Studi Teknik Informatika Fakultas Ilmu Komputer Universitas Lancang Kuning \\ Jl. Yos Sudarso KM. Rumbai, Pekanbaru, Riau, Telp. 08117532015 \\ e-mail: siregarnurholidan@gmail.comzamzami@unilak.ac.id \\ guntoro@unilak.ac.id
}

\begin{abstract}
Abstrak
Pemesanan catering merupakan suatu kegiatan yang dilakukan konsumen untuk pemesanan produk berupa Paket makanan atau catering. Proses pemesanan di Ratu Catering dilakukan dengan datang langsung ke lokasi atau pun melalui telepon sehingga proses pemesanan jadi lama dan kurang efektif. Dan melakukan pencatatan laporan penjualan yang masih manual dengan melakukan pencatatan di buku. Sistem Informasi ini menggunakan sistem Aplikasi berbasis Web yang dibuat dan diimplementasikan menggunakan bahasa pemrograman PHP dan HTML, Dengan Database penyimpanan menggunakan MySQL dan desain sistem dibuat menggunakan UML. serta pengujian sistem dengan Black-Box testing dan keakuratan Sistem Infromasi berdasarkan pengujian pengguna. Hasil penelitian ini bahwa Sistem Informasi Catering dapat mempermudah dalam proses pemesanan catering bagi pelanggan dan mempemudah untuk merekap laporan penjualan.
\end{abstract}

Kata Kunci : Sistem Informasi Pemesanan, Catering, UML, Web

\section{Abstrak}

Catering booking is a consumer-led activity in the form of food packages or catering to order products. The ordering process at Ratu Catering is carried out by going directly to the place or by phone, so that the ordering method takes a long time and is less efficient. And record sales reports that are still manually recorded in the book. This information system uses a web-based application system that is created and implemented using PHP and HTML programming languages, with a MySQL storage database and a UML-based system design. And system testing using Black-Box testing and the catering information system can promote the customer service ordering process and make it simple to review the sales report.

Keywords: Catering, Ordering Information System, UML, Web

\section{Pendahuluan}

Perkembangan bisnis online adalah dampak dari perkembangan teknologi informasi dan komunikasi yang semakin menjadi tuntutan dalam dunia bisnis [1]. Demikian pula di Indonesia, dengan berkembangnya berbagai teknologi informasi dan komunikasi yang dapat dilihat dari popolernya koneksi internet [2] [3]. Internet bukan lagi barang yang asing bagi kebanyakan orang. Penetrasi internet di Indonesia saat ini juga telah mencapai $22 \%$ yang mencerminkan betapa internet sudah merasuk di kalangan masyarakat Indonesia [4].

Internet merupakan jaringan komputer yang saling terhubung secara mendunia untuk memungkinkan jutaan jaringan terhubung satu sama lain sehingga pengguna lebih mudah terhubung dengan pengguna lain [5], jadi, internet merupakan jaringan komputer yang dilengkapi dengan berbagai teknologi yang mendukung pengguna agar bisa berinteraksi satu sama lain dengan pengguna lainnya [6]. Penggunaan internet dalam bisnis pun mengalami 
perkembangan [7], dari pertukaran maupun berbagi informasi secara elektronik ke aplikasi strategi bisnis, seperti pemasaran, penjualan, dan pelayanan terhadap pelanggan [8]

Dengan memanfaatkan Internet banyak develover yang membuat atau mengembangkan suatu aplikasi yang sesuai dengan kebutuhan bisnis termasuk dalam binis kuliner seperti Catering [9]. Ratu Catering merupakan salah satu bisnis di bidang kuliner yang menyediakan paket makanan untuk berbagai acara seperti Pesta, Aqiqah, Acara kantor dan Nasi kotak. Ratu Catering yang beralamat di Jl. Mulya jaya, Limbungan adalah jasa makanan yang didasari dengan harga yang bersahabat dan nikmat. Saat ini sistem penjualan yang dilakukan di Ratu Catering masih manual, dengan melakukan sms, telepon, proses promosi dengan menbagikan brosur dan kartu nama dan dengan datang langsung ke tempat catering.

Permasalahan yang dihadapi dengan pemesanan catering melalui telepon atau datang langsung adalah lamanya proses pemesanan, dan menyita banyak waktu untuk promosi. Cara seperti ini tentunya sangat tidak efektif dan efisien bagi konsumen yang kediamannya jauh dari lokasi Ratu Catering.

Berdasarkan permasalahan tersebut, maka perlunya merancang sebuah website yang bertujuan untuk memperluas jaringan informasi penjualan dan beberapa paket menu yang ditawarkan Ratu Catering. Diharapkan dengan adanya sistem pemesanan katering tersebut dapat mempermudah dalam proses pemesanan oleh Riau Catering maupun konsumen.

\section{Metode Penelitian}

2.1 Pemodelan yang digunakan

Pemodelan yang digunakan untuk perancangan Aplikasi Catering ini menggunanakan metode SDLC Waterfall Model yang digunakan paling awal dalam pengembangan perangkat lunak. Dalam waterfall Model ini suatu alur kerja dari penyebaran komunikasi melalui cara yang cukup linier dengan menunjukkan pendekatan sistematis sekuensial dalam pengembangan perangkat lunak dari spesifikasi kebutuhan pelanggan berlangsung melalui perencanaan, pemodelan, konstruksi dan penyebaran yang berpuncak pada dukungan berkelanjutan dari perangkat lunak yang sudah selesai [10]

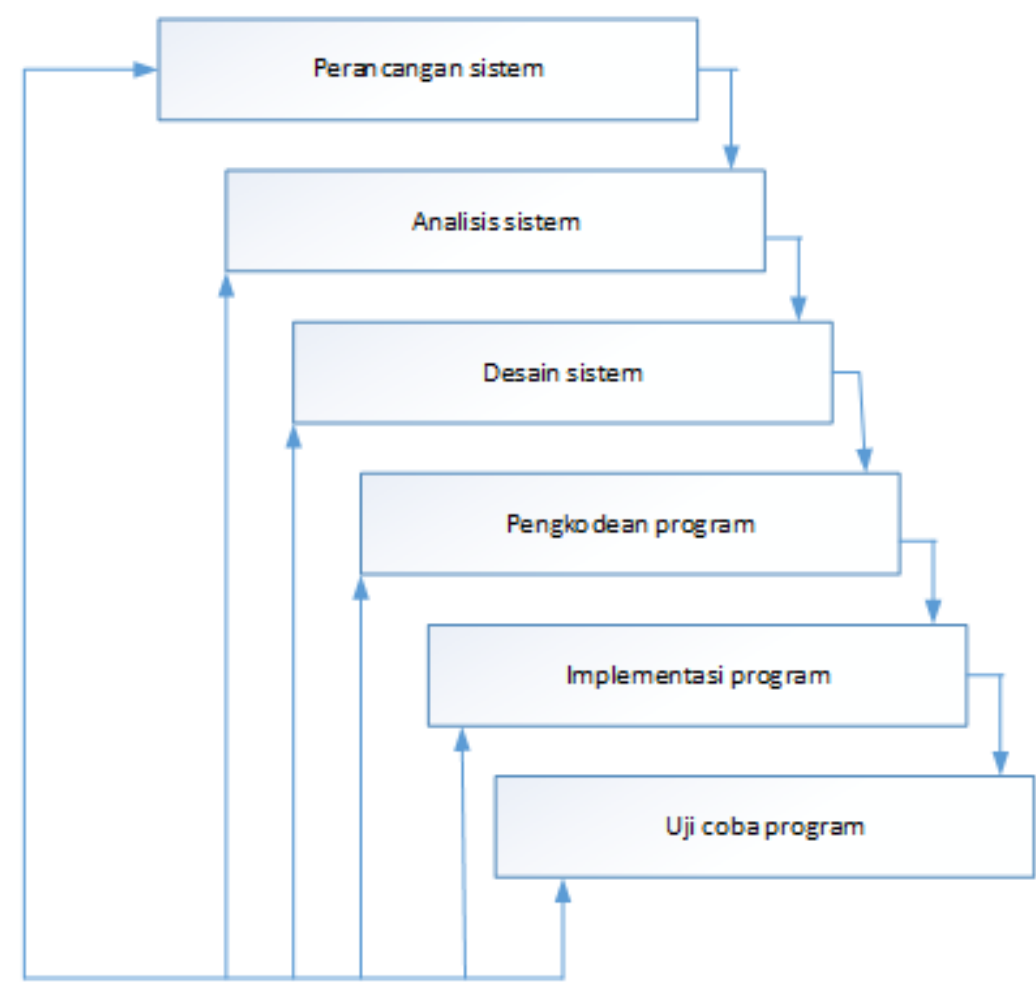

Gambar 1. SLDC Waterfall Model 
Berikut merupakan beberapa tahapan pengembangan Model Sekuensial Linier / Waterfall Development Model :

1. Pencangan sistem

Tahap pertama mulai membangun elemen sistem dan memilih bagian mana saja yang akan digunakan sebagai bahan pengembangan perangkat lunak, dengan memperhatikan hubungan dengan hardware, Database dan User.

2. Analisis sistem

Tahap ini melakukan analisa dan mengumpulkan kebutuhan-kebutuhan sistem seperti fungsi yang diperlukan untuk performansi/ kerja dan antarmuka. Hasil anlaisa dan kumpulan data tersebut didokumentasikan.

3. Desain sistem

Tahap ini proses desain, dilakukan dengan menerjemahkan syarat kebutuhan suatu perancangan perangkat lunak yang bisa diperkirakan sebelum dibuatnya proses pengkodean (coding).

4. Pengkodean program

Tahap pengkodean ini adalah proses penerjemahan perancangan desain ke dalam bentuk yang bisa dimengerti oleh mesin menggunakan bahasa pemrograman.

5. Implementasi sistem

Tahapan akhir desain program dibangun diterjemahkan ke dalam kode-kode yang menggunakan bahasa pemrograman dan langsung diuji secara unit.

6. Uji coba program

Proses pengujian logika internal dan pengujian eksternal fungsional terhadap program perangkat lunak, untuk memeriksa segala kemungkinan yang dapat terjadi seperti kesalahan dan juga memeriksa apakah hasil pengembangannya sesuai dengan yang dirancang.

\section{Hasil dan Pembahasan}

3.1 Implementasi Sistem

Tahap ini merupakan tahap dimana aplikasi siap digunakan, sehingga dapat diketahui apakah aplikasi ini berjalan sesuai dengan apa yang telah dirancang. Pada tahap ini akan dijelaskan bagaimana aplikasi ini bekerja dengan menampilkan yang dibuat.

1. Tampilan Awal

Tampilan awal dari sistem pelayanan administrasi terpadu kecamatan

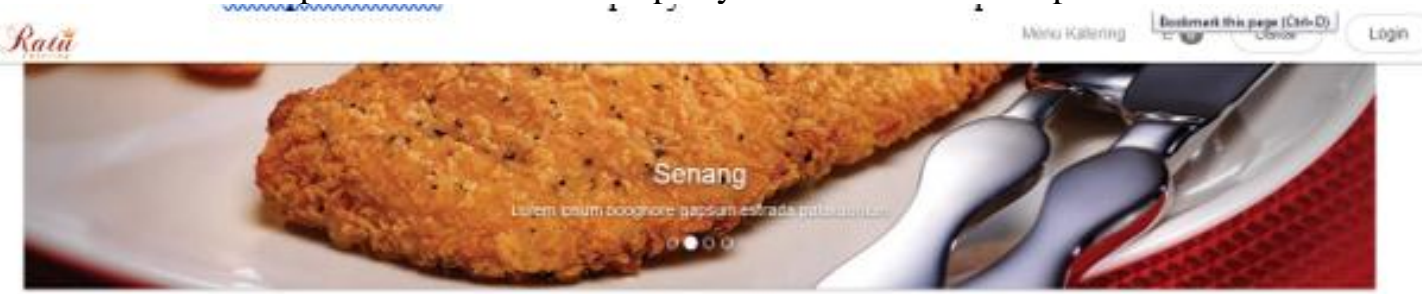

Paket Katering

pesas berasanan panet motat an koh hemo
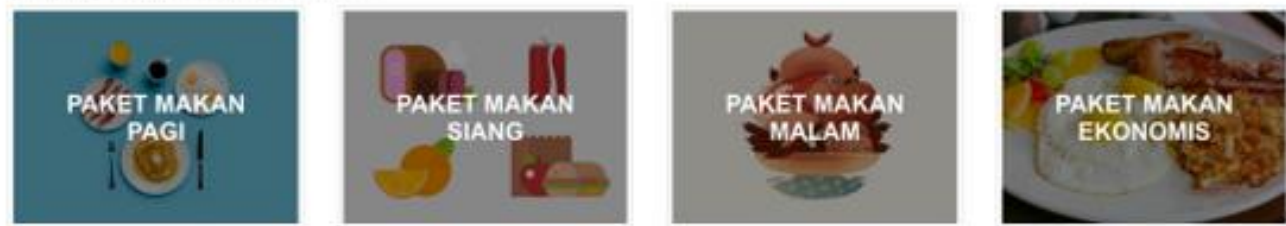

Gambar 2. Tampilan Awal Sistem informasi catering

2. Tampilan Login

Tampilan menu ini berupa form login admin yang harus diisi untuk masuk ke aplikasi. 


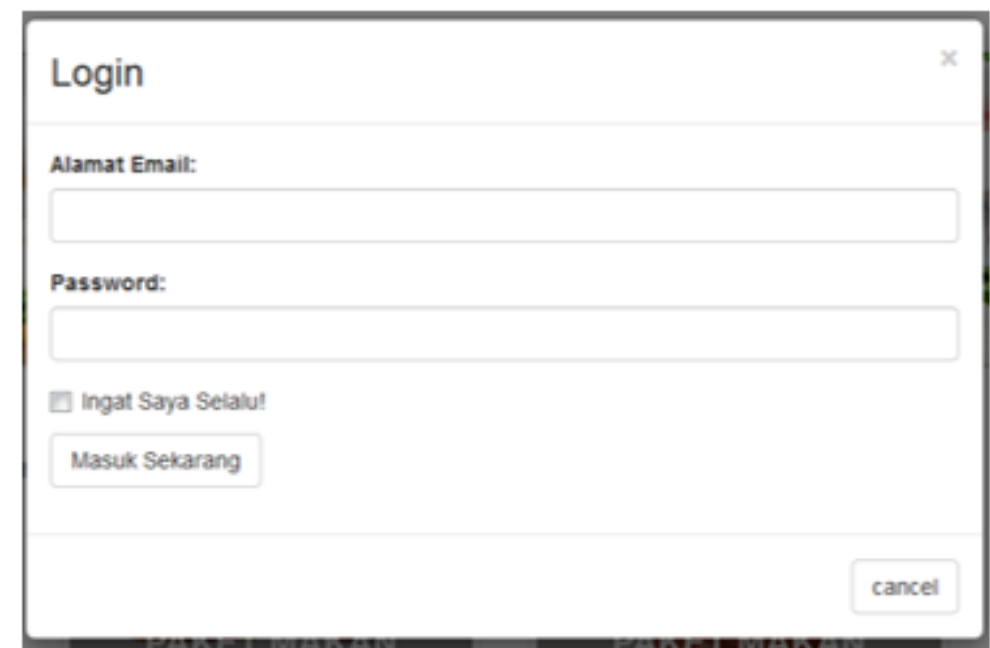

Gambar 3. Tampilan Menu Login

3. Tampilan Menu Admin

Tampilan menu utama terdiri dari menu pesanan masuk, bukti bayar masuk, lihat dan tambah menu, riwayat pembayaran, data pengguna, data penjualan, laporan penjualan dan logout. Tampilannya sebagai berikut:

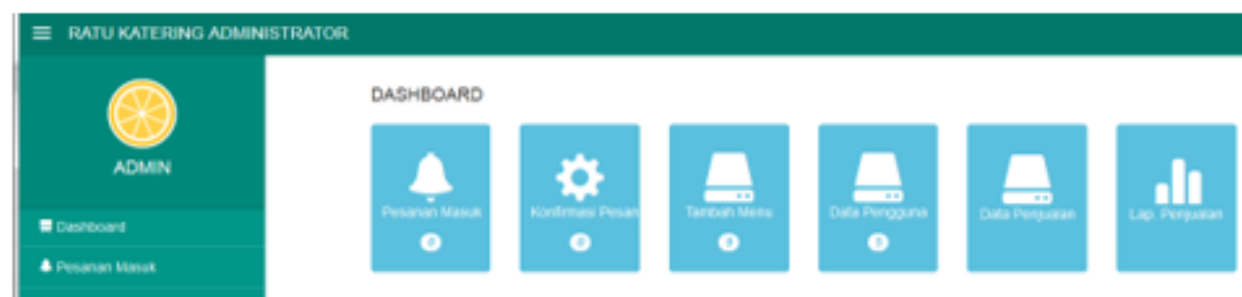

4 Bastapa mena

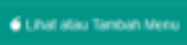

Emapar reneapasen

ecuta Proman

Ecata Penaian

Aluporm Aryman

Ologat

Gambar 4. Tampilan Menu Admin

4. Tampilan Menu pesanan masuk

Pada tahapan ini merupakan tampilan menu pesanan masuk. 


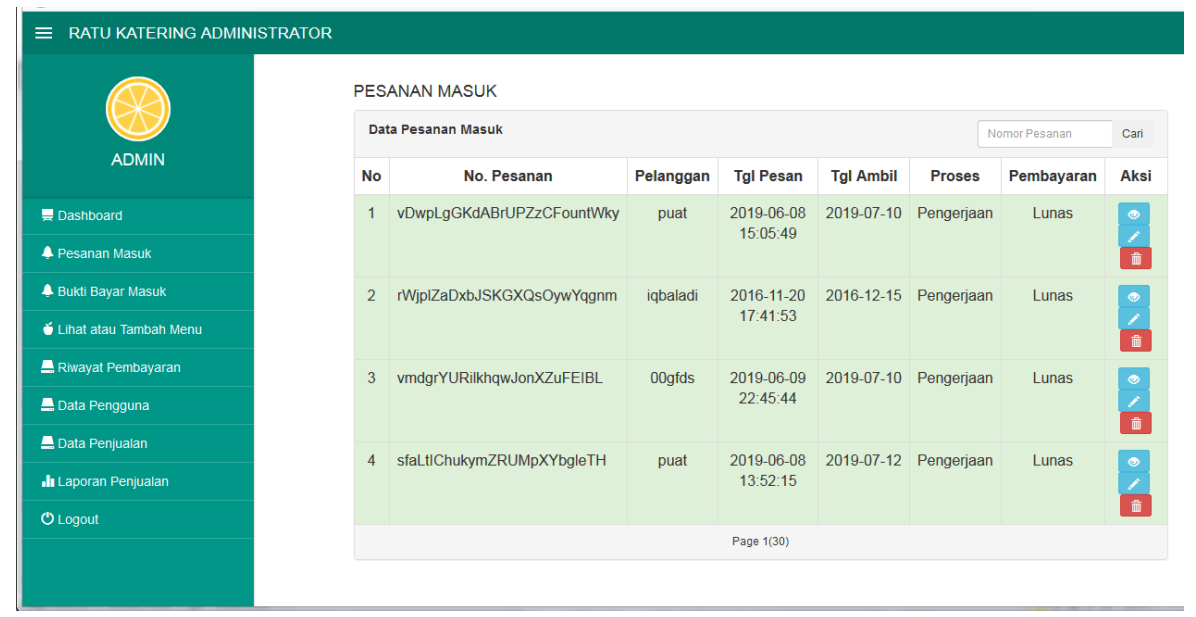

Gambar 5. Tampilan pesanan masuk

5. Tampilan Menu bukti bayar masuk

Jika admin memilih menu bukti bayar masuk maka tampilan nya sebagai berikut:

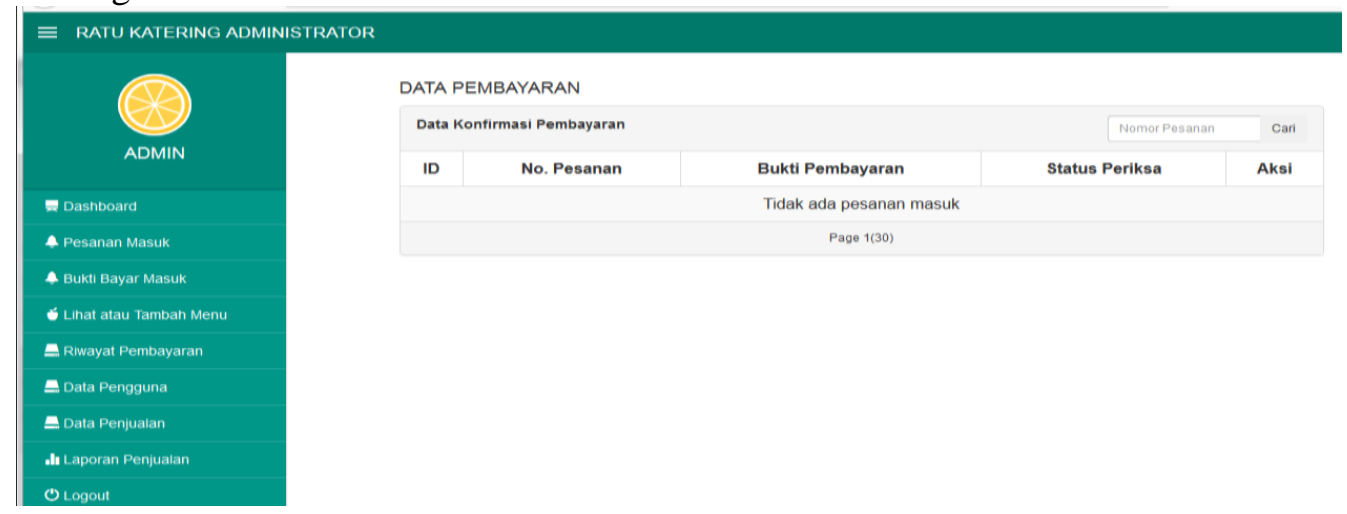

Gambar 6. Tampilan Menu bukti bayar masuk

6. Tampilan Menu lihat tambah menu

Tampilan lihat dan tambah menu sebagai berikut:

\begin{tabular}{|c|c|c|c|c|c|c|}
\hline \multicolumn{7}{|c|}{$\equiv$ RATU KATERING ADMINISTRATOR } \\
\hline \multirow{2}{*}{ ADMIN } & \multicolumn{3}{|c|}{ Data Menu Tersedia } & \multicolumn{2}{|l|}{ Nama Menu } & \multirow{2}{*}{$\begin{array}{l}\text { Tambah Menu } \\
\text { Aksi }\end{array}$} \\
\hline & No & Kd Menu & Nama Menu & Harga & & \\
\hline Eashboard & 1 & 7 & Nasi Ayam Goreng & Rp. 10.000,- & & 右血 \\
\hline A Pesanan Masuk & 2 & 8 & Nasi Telur Pedas & Rp. 7.000,- & & - 1 1 而 \\
\hline 4 Bukit Bayar Masuk & 3 & 9 & Nasi Telur dan Ayam & Rp. 13.000,- & & 原血 \\
\hline CLihat atau Tambah Menu & 4 & 10 & Nasi Rames & Rp. $6.000,-$ & & 长血 \\
\hline A Riwayat Pembayaran & 5 & 11 & Gado-Gado & Rp. 10.000,- & & - 1 而 \\
\hline Data Pengguna & 6 & 12 & Nasi Rica-Rica Ayam & Rp. 10.000,- & & 01 \\
\hline D Data Penjualan & 7 & 13 & Kupat Tahu & Rp. 8.000,- & & 长血 \\
\hline In Laporan Penjualan & 8 & 14 & Mangut Lele & Rp. 10.000,- & & 吅自 \\
\hline \multirow[t]{2}{*}{ O Logout } & 9 & 15 & Mangut Ayam & Rp. 10.000,- & & 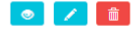 \\
\hline & \multicolumn{6}{|c|}{ Page 1(30) } \\
\hline
\end{tabular}

Gambar 7. Tampilan Menu lihat tambah menu

7. Tampilan menu riwayat pembayaran

Jika admin memilih menu riwayat pembayaran, berikut tampilan nya: 


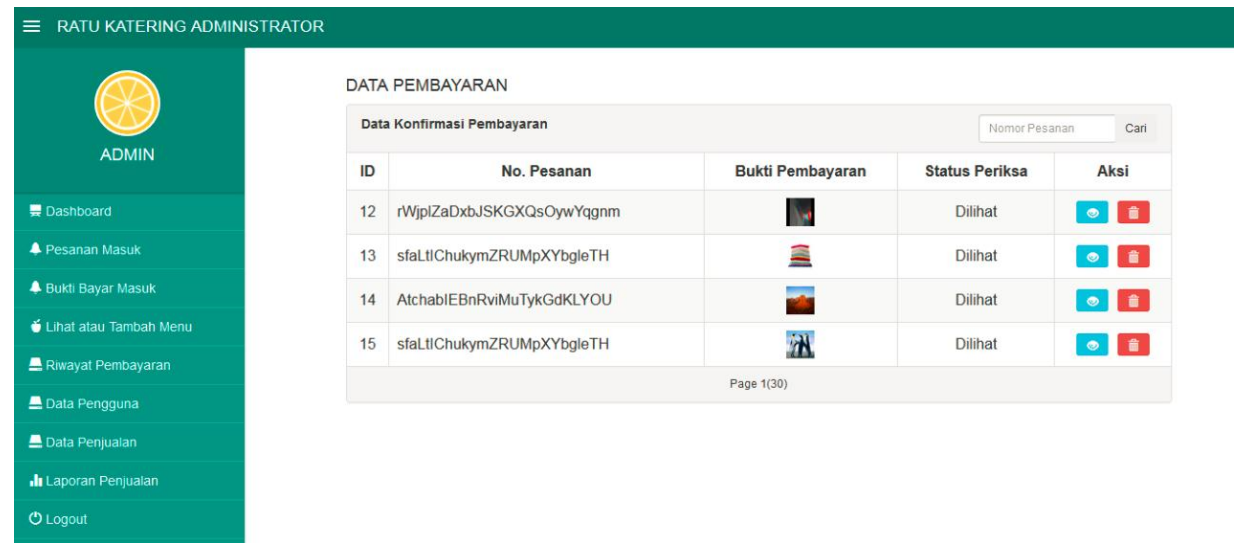

Gambar 8. Tampilan Menu riwayat pembayaran

8. Tampilan data pengguna

Jika admin memilih menu data pengguna, berikut tampilan nya:

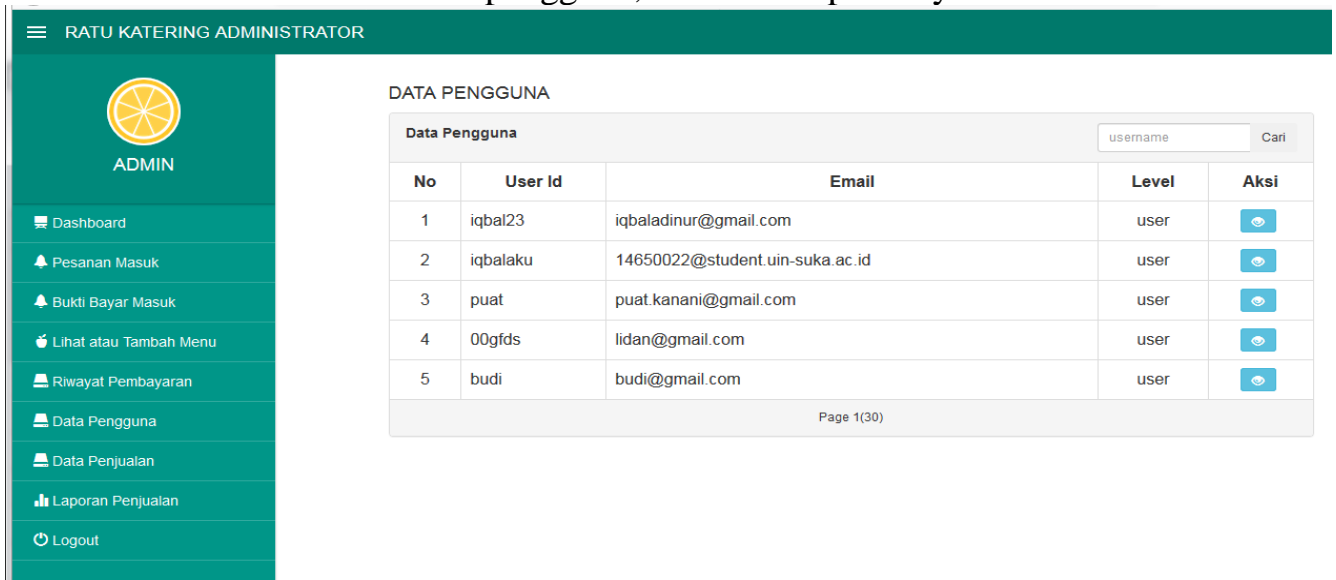

Gambar 9. Tampilan Data pengguna

9. Tampilan data penjualan

Jika admin melihat menu data penjualan, berikut tampilan nya:
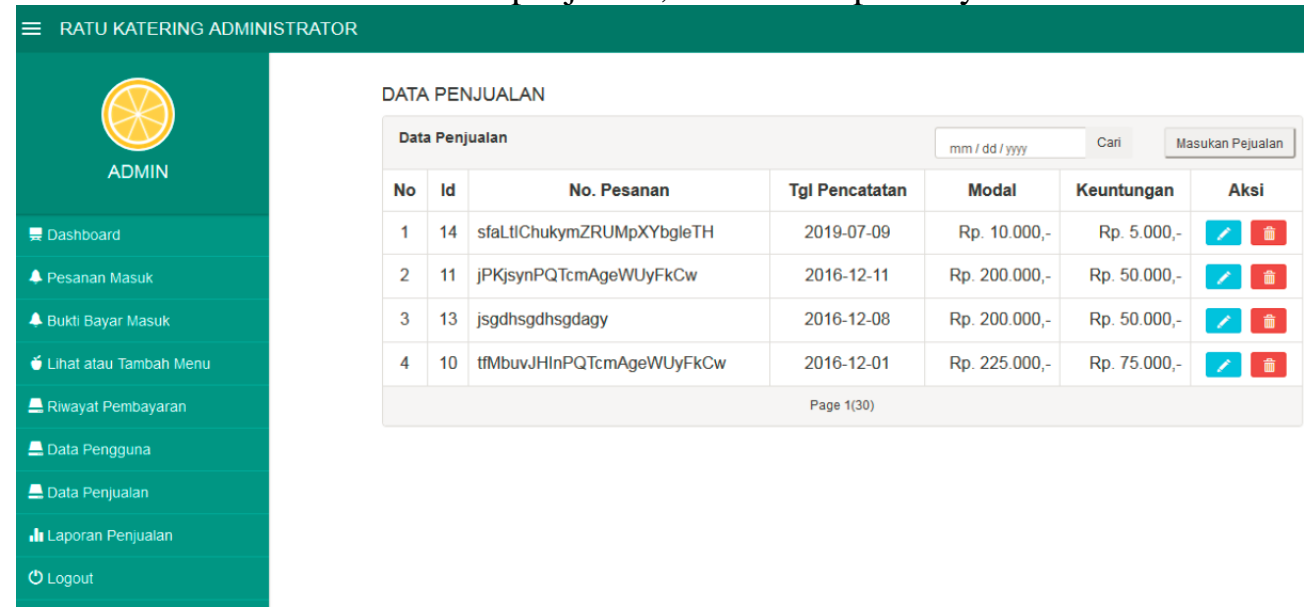

Gambar 10. Tampilan data pengguna

10. Tampilan laporan penjualan

Jika admin melihat menu laporan penjualan, berikut tampilan nya: 


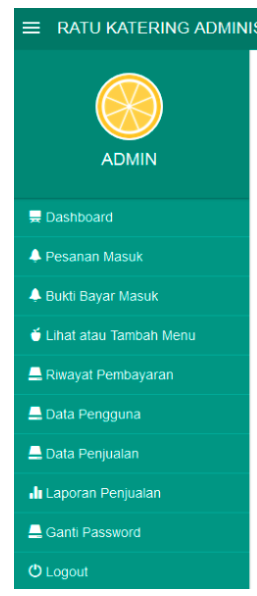

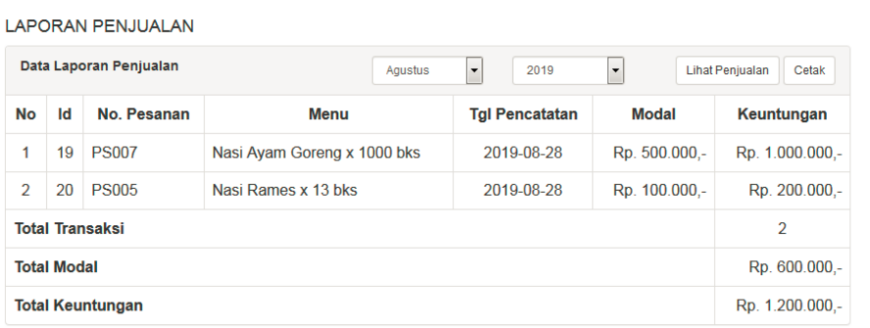

Gambar 11. Tampilan laporan penjualan

11. Tampilan Output Laporan Penjualan

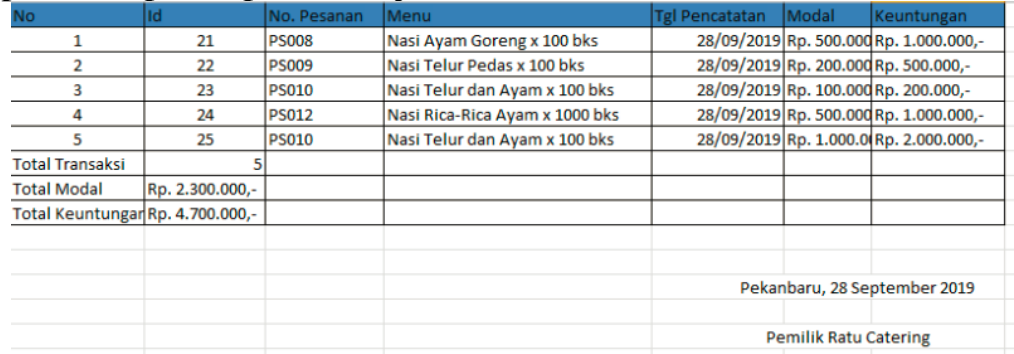

Gambar 12. Tampilan Output laporan penjualan

12. Tampilan menu catering

Tampilan menu catering. Berikut tampilannya.

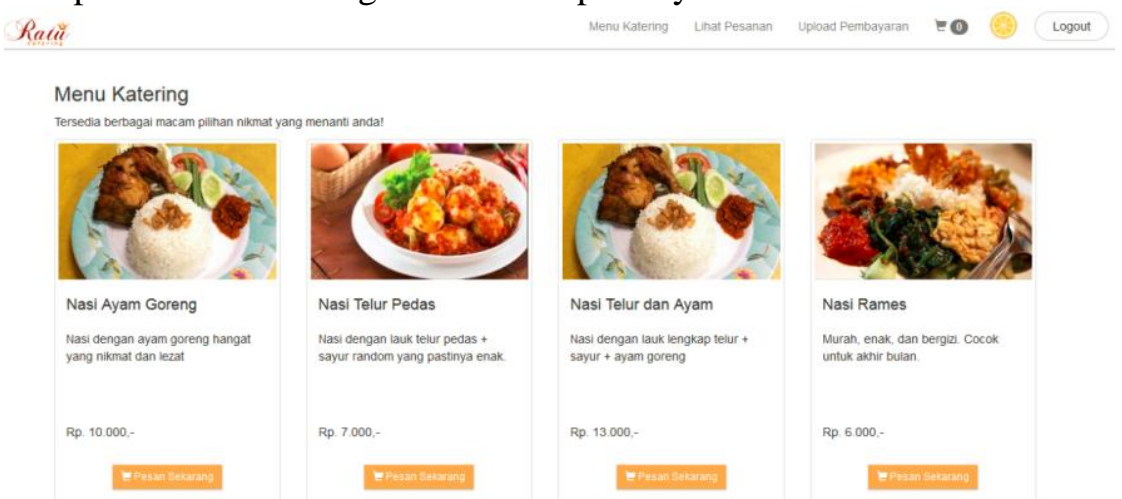

Gambar 13. Tampilan menu catering

13. Tampilan Keranjang Pesanan

Tampilan ini akan menampilkan keranjang untuk pemesanan catering. 


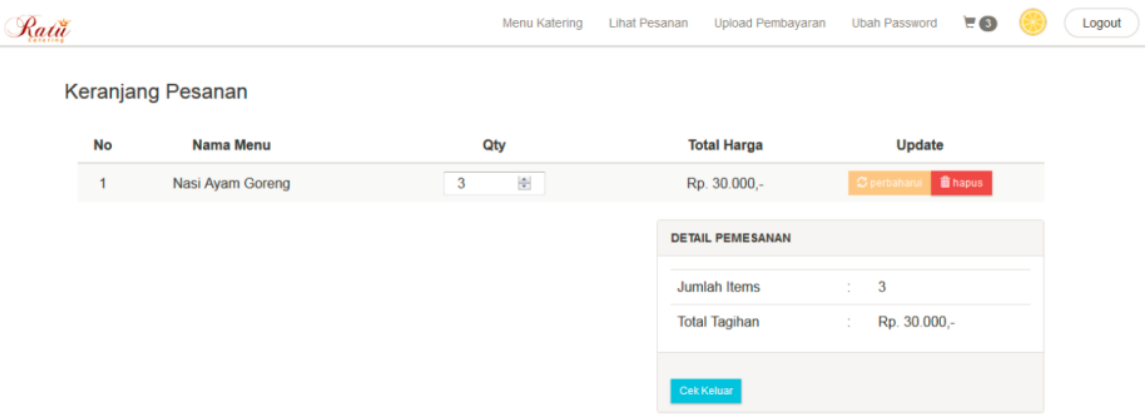

Gambar 14. Tampilan Keranjang Pesanan

14. Tampilan Proses Pemesanan

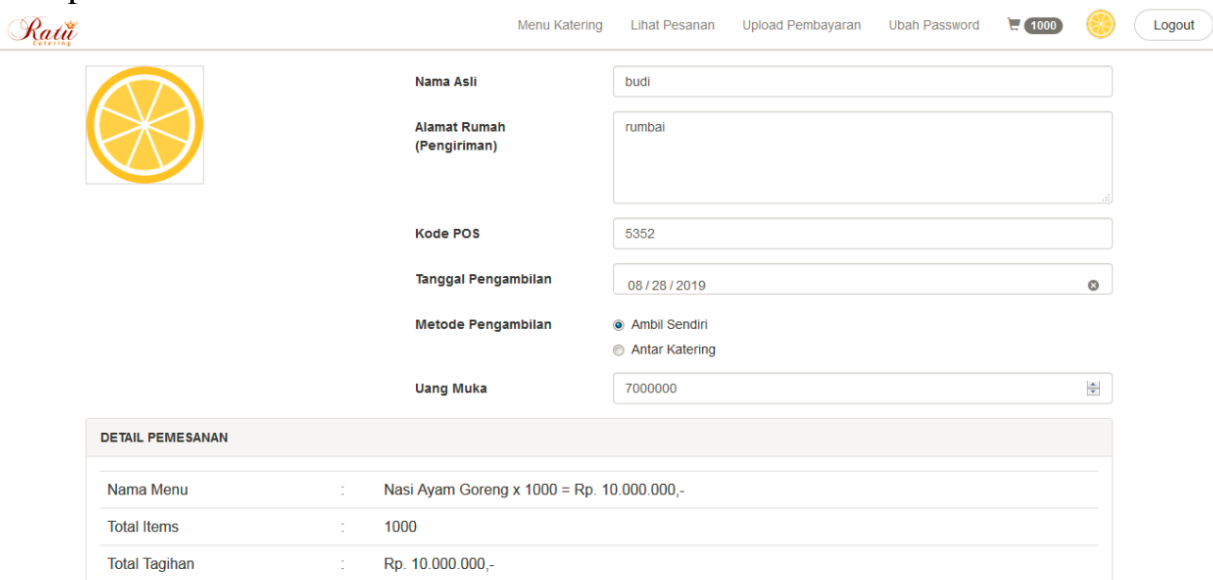

Gambar 15. Tampilan Proses Pemesanan

15. Tampilan Tagihan Pemesanan

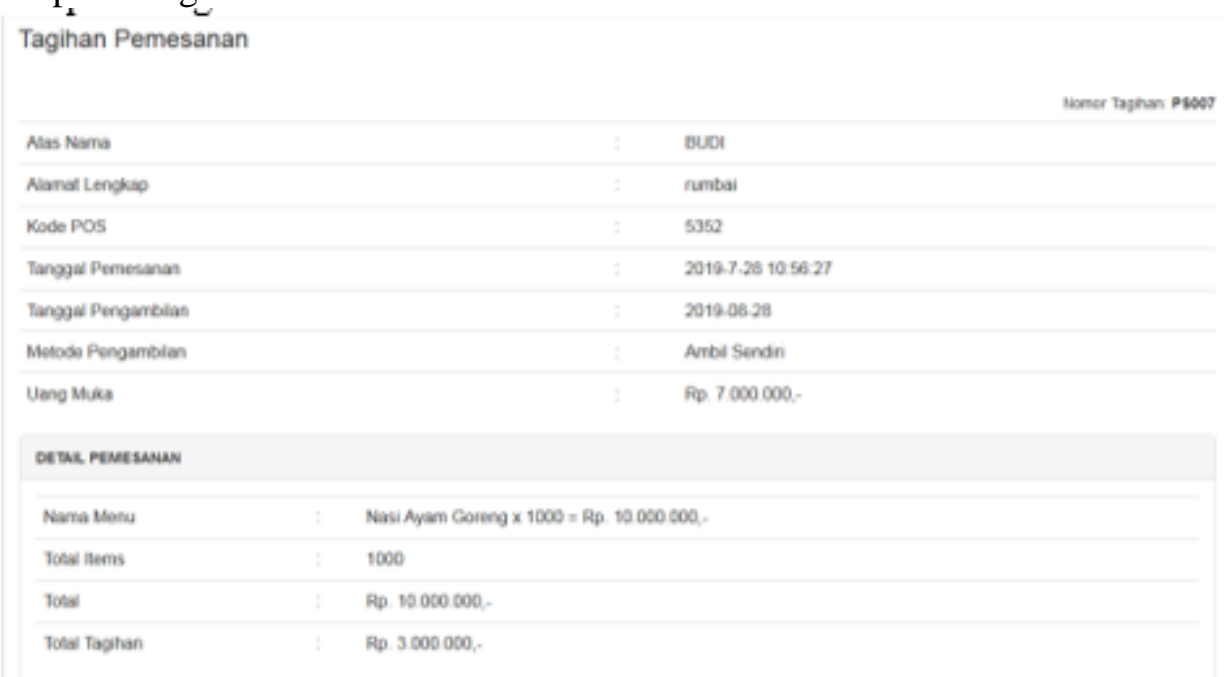

Gambar 16. Tampilan Tagihan Pemesanan 
16. Tampilan Upload Bukti pembayaran

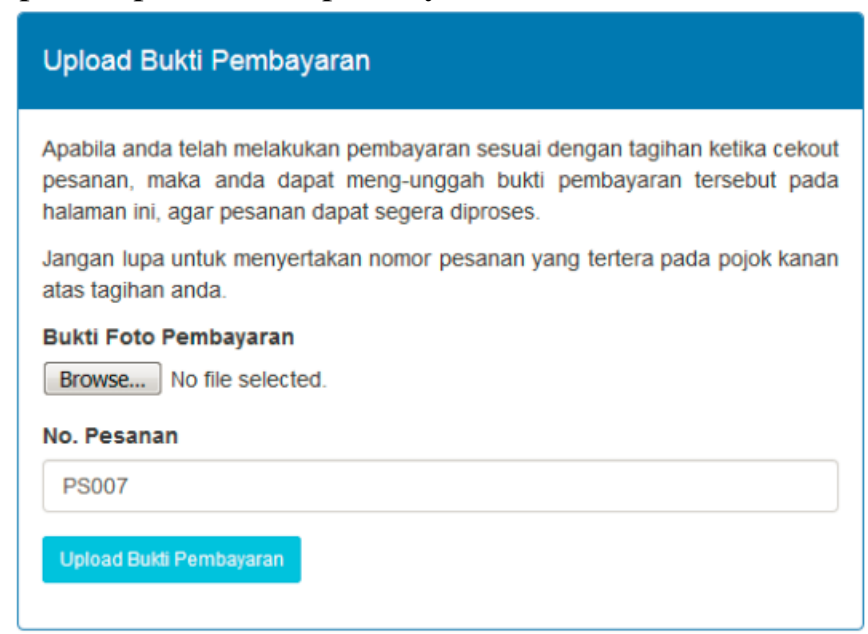

Gambar 17. Tampilan Upload Bukti pembayaran

17. Tampilan lihat pesanan

Tampilan menu pengguna menampilkan nama pengguna yang dapat login ke menu lihat pesanan.

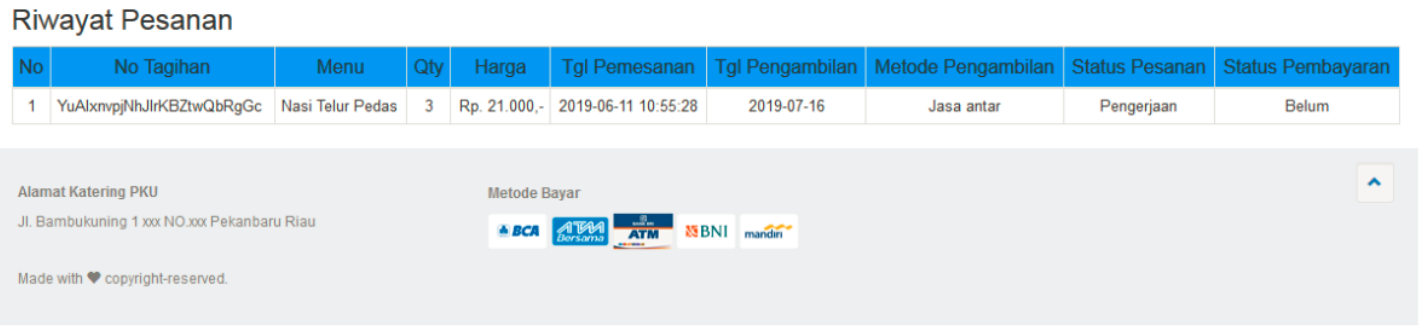

Gambar 18. Tampilan riwayat pesanan

\subsection{Pengujian Dengan Black Box}

Sistem pengujian yang di buat dalam sitem aplikasi ini adalah pengujian Black box. Dimana Black Box pengujian itu sendiri adalah metode pengujian perangkat lunak yang dilakukan hanya mengamati hasil eksekusi melalui data uji dan memeriksa fungsional dari perangkat lunak di fokuskan untuk tampilan hasil interfacenya saja.

a. Kasus dan Hasil Pengujian

Dalam Pengujian ini penulis akan mengambil contoh kasus dari tahap pengujian program terhadap kesesuain dengan kebutuhan sistem, diantaranya:

Tabel 1. Tabel Pengujian User

\begin{tabular}{llllll} 
No & Nama Form & Skenario Pengujian & Hasil yang diharapkan & $\begin{array}{c}\text { Hasil } \\
\text { Pengujian }\end{array}$ \\
\hline 1 & Form Login User & $\begin{array}{l}\text { Mengisi username dan } \\
\text { password dengan benar }\end{array}$ & $\begin{array}{l}\text { Berhasil masuki ke } \\
\text { halaman admin }\end{array}$ & Valid \\
Salah mengisi username & $\begin{array}{l}\text { Tidak bisa masuk ke } \\
\text { halaman admin }\end{array}$ & \\
\hline 2 & Register & $\begin{array}{l}\text { Mengisi semua form } \\
\text { register / tidak mengisi } \\
\text { semua form register }\end{array}$ & $\begin{array}{l}\text { Berhasil melakukan Valid } \\
\text { register / Berhasil } \\
\text { melakukan register }\end{array}$ & \\
\hline
\end{tabular}




\begin{tabular}{|c|c|c|c|c|}
\hline 3 & $\begin{array}{l}\text { Form } \\
\text { Catering }\end{array}$ & $\begin{array}{l}\text { Lihat menu dan harga } \\
\text { menu }\end{array}$ & $\begin{array}{l}\text { Berhasil melihat menu } \\
\text { dan lihat harga }\end{array}$ & Valid \\
\hline 4 & $\begin{array}{l}\text { Form Upload } \\
\text { pembayaran }\end{array}$ & Upload pembayaran & Berhasil di upload & Valid \\
\hline \multicolumn{5}{|c|}{ Tabel 2. Tabel Pengujian Login Admin } \\
\hline No & Nama Form & Skenario Pengujian & Hasil yang diharapkan & $\begin{array}{l}\text { Hasil } \\
\text { Pengujian }\end{array}$ \\
\hline 1 & Form Login Admin & $\begin{array}{l}\text { Mengisi username dan } \\
\text { password dengan benar } \\
\text { Salah mengisi username } \\
\text { dan password }\end{array}$ & $\begin{array}{l}\text { Berhasil masuki } \mathrm{ke} \\
\text { halaman admin } \\
\text { Tidak bisa masuk ke } \\
\text { halaman admin }\end{array}$ & Valid \\
\hline
\end{tabular}

Tabel 3. Tabel Pengujian Black Box Menu Admin

\begin{tabular}{|c|c|c|c|c|}
\hline No & Nama Form & Skenario Pengujian & Hasil yang diharapkan & $\begin{array}{c}\text { Hasil } \\
\text { Pengujian }\end{array}$ \\
\hline 1 & $\begin{array}{l}\text { Form } \\
\text { Pesanan } \\
\text { Masuk }\end{array}$ & $\begin{array}{l}\text { Melihat detail pesanan } \\
\text { Memperbarui status pembayaran } \\
\text { Menghapus Pesanan }\end{array}$ & $\begin{array}{l}\text { Berhasil melihat detail } \\
\text { pesanan } \\
\text { Berhasil memperbarui } \\
\text { status pembayaran } \\
\text { Berhasil menghapus } \\
\text { pesanan }\end{array}$ & Valid \\
\hline 2 & $\begin{array}{l}\text { Form Bukti } \\
\text { Bayar masuk }\end{array}$ & $\begin{array}{l}\text { Lihat bukti pembayaran } \\
\text { Cek nomor pesanan }\end{array}$ & $\begin{array}{l}\text { Berhasil melihat } \\
\begin{array}{l}\text { Berhasil cek nomor } \\
\text { pesanan }\end{array}\end{array}$ & Valid \\
\hline 3 & $\begin{array}{l}\text { Form Lihat } \\
\text { dan tambah } \\
\text { menu }\end{array}$ & $\begin{array}{l}\text { Melihat detail menu } \\
\text { Menambah Jenis Perizinan } \\
\text { Mengubah Jenis Perizinan } \\
\text { Menghapus Jenis Perizinan }\end{array}$ & $\begin{array}{l}\text { Berhasil di lihat } \\
\text { Berhasil di tambah } \\
\text { Berhasil di rubah } \\
\text { Berhasil di hapus }\end{array}$ & Valid \\
\hline 4 & $\begin{array}{l}\text { Form } \\
\text { Riwayat } \\
\text { Pembayaran }\end{array}$ & $\begin{array}{l}\text { Melihat bukti Pembayaran } \\
\text { Mencari Nomor pesanan } \\
\text { Menghapus pesanan }\end{array}$ & $\begin{array}{l}\text { Berhasil di lihat } \\
\text { Berhasil di cari } \\
\text { Berhasil di hapus }\end{array}$ & Valid \\
\hline 5 & $\begin{array}{l}\text { Form Data } \\
\text { Pengguna }\end{array}$ & $\begin{array}{l}\text { Mencari username } \\
\text { Melihat detail pengguna }\end{array}$ & $\begin{array}{l}\text { Berhasil di cari } \\
\text { Berhasil di lihat }\end{array}$ & Valid \\
\hline 6 & $\begin{array}{l}\text { Form Data } \\
\text { penjualan }\end{array}$ & $\begin{array}{l}\text { Tambah penjualan } \\
\text { Edit Data penjualan } \\
\text { Hapus penjualan }\end{array}$ & $\begin{array}{l}\text { Berhasil di Tambah } \\
\text { Berhasil di Edit } \\
\text { Berhasil di hapus }\end{array}$ & Valid \\
\hline 7 & Form laporan & $\begin{array}{l}\text { Lihat penjulan } \\
\text { Cetak laporan }\end{array}$ & $\begin{array}{l}\text { Berhasil di lihat } \\
\text { Berhasil di cetak }\end{array}$ & Valid \\
\hline 8 & Logout & Keluar & Berhasil keluar & valid \\
\hline
\end{tabular}




\section{Kesimpulan}

Dari penelitian ini penulis dapat memberikan kesimpulan dari hasil penelitian yang telah dilakukan sebagai berikut:

1. Dengan adanya sistem ini, maka pihak catering dapat dimudahkan untuk melihat pesanan catering dan merekap laporan penjualan catering.

2. Dengan adanya sistem ini, dapat membantu pelanggan untuk melakukan pemesanan catering dan melihat menu-menu catering yang disediakan oleh Ratu Catering

3. Berdasarkan pengujian yang telah dilakukan, aplikasi sistem pemesan catering dapat berjalan dengan baik.

\section{DAFTAR PUSTAKA}

[1] B. Uddin, "Aplikasi Pemesanan Catering Menggunakan SMS Gateway Berbasis Web," J. Telemat., vol. 12, no. 1, pp. 71-76, 2017.

[2] Guntoro, B. Hamuddin, and B. Febriadi, "RANCANG BANGUN PORTAL INTERNATIONAL CONFERENCE ON ENVIRONMENT AND TECHNOLOGY (IceTech) UNIVERSITAS LANCANG KUNING," JIPI (Jurnal Ilm. Penelit. dan Pembelajaran Inform., vol. 04, no. 01, pp. 28-35, 2019.

[3] J. O. Sembiring, "Sistem Informasi Pemesanan Dan Penjualan Barang pada Pintera Kreativ Berbasis Web," MEANS (Media Inf. Anal. dan Sist., vol. 2, no. 2, pp. 146-152, 2017.

[4] A. Maryanto and C. Kesuma, "Sistem Informasi Pemesanan Makanan Dan Minuman Berbasis Web Pada Rumah Makan Gazebo Purwokerto," Indones. J. Netw. Secur., vol. 6, no. 4, pp. 1-8, 2017.

[5] D. Permata, E. Tasrif, and I. P. Dewi, "PERANCANGAN SISTEM INFORMASI PEMESANAN WEDDING ORGANIZER DI KOTA PADANG," J. Vokasional Tek. Elektron. dan Inform., vol. 6, no. 1, pp. 2-7, 2018.

[6] I. Inayati, M. N. Hidayatulloh, and M. Kamisutara, "APLIKASI PEMESANAN MAKANAN BERBASIS WEB ( Studi Kasus: RM Lesehan Berkah Ilaahi Gresik )," $e$ NARODROID, vol. 1, no. 2, pp. 80-86, 2015.

[7] A. Fauzi, Erniawati, and A. S. H, "SISTEM INFORMASI PEMESANAN KERTAS CONTINUOUS FORM," J. Teknol. Inform. dan Komput., vol. 5, no. 1, pp. 123-127, 2019.

[8] Khairunnisa and F. Damayanti, "Pengolahan Bisnis Catering Ummi Nisa Medan Berbasis Web," QUERY J. Sist. Inf., vol. 2, no. 1, pp. 63-71, 2018.

[9] Fatmawati, "Perancangan Sistem Informasi Pemesanan Katering Berbasis Web Pada Rumah Makan Tosuka Tangerang,” J. Tek. Komput., vol. II, no. 2, pp. 33-41, 2016.

[10] I. Sommerville, Software Engineering (9th Edition). Pearson, 2011. 